\title{
U.S. Geological Survey Assessment of Undiscovered Petroleum Resources of the Hamra Basin, Libya, 2006
}

\footnotetext{
Jing a geology-based assessment methodology, the U.S. Geological Survey estimated mean volumes of 784 million barrels of crude oil, 4,748 billion cubic feet of natural gas, and 381 million barrels of natural gas liquids in the Hamra Basin of northwestern Libya. Most of the undiscovered crude oil and natural gas are interpreted to be in deeper parts of the Hamra Basin.
}

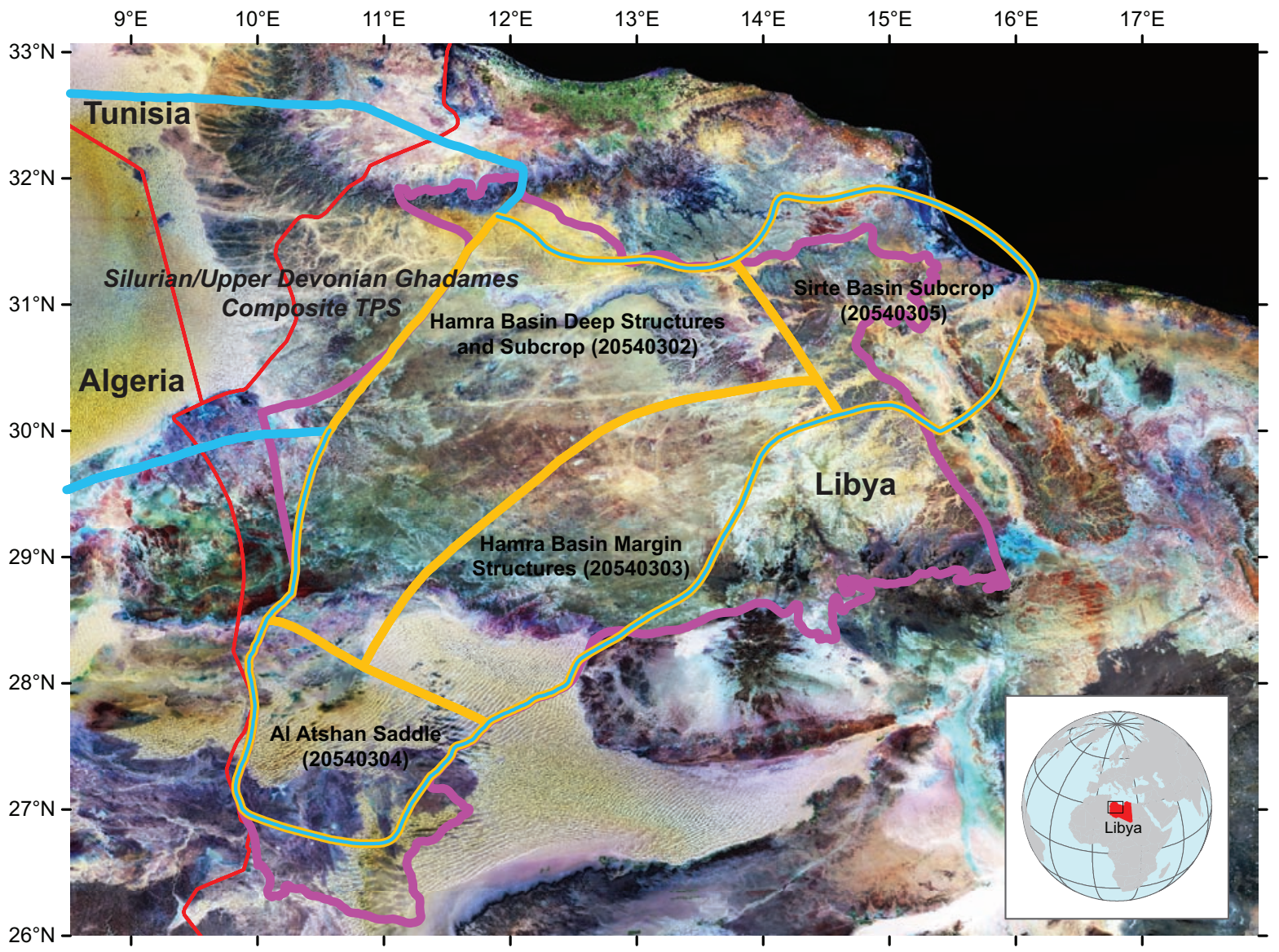

Figure 1. Satellite image of northwestern Libya showing locations of the Hamra Basin (pink line), the Silurian/ Upper Devonian Ghadames Composite TPS (blue line), and the four assessment units (orange lines); Hamra Basin Deep Structures and Subcrop (20540302), Hamra Basin Margin Structures (20540303), Al Atshan Saddle (20540304), and Sirte Basin Subcrop (20540305). Some of the TPS boundaries extend west and north beyond the area of the image. Red lines are country boundaries. Satellite image (Landsat Orthorectified TM Mosaic) from U.S. Geological Survey.

\section{Introduction}

U.S. Geological Survey (USGS) assessments of undiscovered crude oil and natural gas resources are based on the geologic elements of a total petroleum system (TPS), which include (1) source-rock presence, maturation, petroleum generation, and migration; (2) distribution and quality of reservoir rocks; and (3) character of traps and time of formation with respect to petroleum migration. Data from detailed studies of geochemistry, petroleum geology, geophysics, and tectonics combined with historical exploration and production analyses are used to 
aid in the estimation of the number and sizes of undiscovered petroleum accumulations.

The Hamra Basin Province encompasses approximately 244,100 square kilometers (94,250 square miles) and is entirely within Libya. One composite TPS was defined for this assessment; it extends from Libya westward into adjacent parts of Algeria and southern Tunisia (fig. 1). The Hamra Basin part of the TPS was subdivided into four assessment units (AU) for the purpose of resource assessment (table 1). The assessment units cover only 172,390 square kilometers of the Hamra Basin Province; the remaining area has little potential for undiscovered petroleum resources because of the absence of petroleum source rocks. Much of the petroleum resource potential is located in the Hamra Basin Deep Structures and Subcrop AU (fig. 1). Although several crude oil and natural gas discoveries were made across the basin, few areas are presently producing. Most discoveries were made in Upper Silurian and Lower Devonian paralic and nearshore marine clastic reservoirs beneath impermeable mudstone seals. Traps include anticlines, faults, and pinchouts beneath erosional unconformities.

Potential for undiscovered petroleum accumulations exists in Ordovician, Upper Devonian, and Carboniferous reservoirs.

\section{Resource Summary}

Using a geology-based assessment methodology, the USGS estimated mean volumes of undiscovered conventional, technically recoverable petroleum (discovered reserves not included) in the Hamra Basin of northwestern Libya. The estimated mean volumes of a probability distribution are 784 million barrels (107 million metric tons) of crude oil, 4,748 billion cubic feet ( 134 billion cubic meters) of natural gas, and 381 million barrels (52 million metric tons) of natural gas liquids. Most of the undiscovered crude oil and natural gas is interpreted to be in deeper parts of the Hamra Basin, in the Hamra Basin Deep Structures and Subcrop AU (20540302). Little potential for undiscovered petroleum exists in the Sirte Basin Subcrop AU (20540305), because seals are interpreted to be poor or absent.

\section{Further Information}

Supporting geologic studies of total petroleum systems and assessment units, as well as reports on the methodology used in the Hamra Basin petroleum resource assessment, are in progress. Assessment results are available at the USGS Central Energy Team Web site: http://energy.cr.usgs.gov/oilgas/

\section{Contact}

T.R. Klett, U.S. Geological Survey

Box 25046, Denver Federal Center, MS 939

Denver, CO 80225 U.S.A.

3032365841 tklett@usgs.gov

Table 1. Hamra Basin Assessment Results (reserves not included).

[MMB, million barrels. BCF, billion cubic feet. Results shown are fully risked estimates. For gas fields, all liquids are included under the natural gas liquids (NGL) category. F95 denotes a 95 percent chance of at least the amount tabulated. Other fractiles are defined similarly. Fractiles are additive under the assumption of perfect positive correlation. TPS, total petroleum system. AU, assessment unit. Gray shading indicates not applicable]

\begin{tabular}{|c|c|c|c|c|c|c|c|c|c|c|c|c|c|}
\hline \multirow{2}{*}{$\begin{array}{l}\text { Total Petroleum Systems } \\
\text { (TPS) } \\
\text { and Assessment Units (AU) }\end{array}$} & \multirow{2}{*}{$\begin{array}{l}\text { Field } \\
\text { Type }\end{array}$} & \multicolumn{12}{|c|}{$\begin{array}{c}\text { Total Undiscovered Resources } \\
\text { Gas (BCF) }\end{array}$} \\
\hline & & F95 & F50 & F5 & Mean & F95 & $\mathrm{F} 50$ & F5 & Mean & F95 & F50 & F5 & Mean \\
\hline \multicolumn{14}{|c|}{$\begin{array}{l}\text { HAMRA BASIN PROVINCE (2047) } \\
\text { Silurian/Upper Devonian-Ghadames Composite TPS (205403) }\end{array}$} \\
\hline \multirow{2}{*}{$\begin{array}{l}\text { Hamra Basin Deep Structures } \\
\text { and Subcrop AU (20540302) }\end{array}$} & Oil & 124 & 430 & 841 & 451 & 232 & 836 & 1,801 & 902 & 9 & 32 & 76 & 36 \\
\hline & Gas & & & & & 556 & 2,010 & 4,088 & 2,130 & 51 & 195 & 437 & 213 \\
\hline & & & & & & & & & & & & & \\
\hline \multirow{2}{*}{$\begin{array}{l}\text { Hamra Basin Margin Structures } \\
\text { AU (20540303) }\end{array}$} & Oil & 42 & 190 & 499 & 220 & 79 & 369 & 1,042 & 439 & 3 & 14 & 43 & 18 \\
\hline & Gas & & & & & 80 & 400 & 1,411 & 525 & 8 & 39 & 143 & 52 \\
\hline & & & & & & & & & & & & & \\
\hline \multirow{2}{*}{ Al Atshan Saddle AU (20540304) } & Oil & 13 & 66 & 232 & 87 & 25 & 130 & 476 & 174 & 1 & 5 & 20 & 7 \\
\hline & Gas & & & & & 81 & 399 & 1,421 & 526 & 7 & 39 & 145 & 53 \\
\hline & & & & & & & & & & & & & \\
\hline \multirow{2}{*}{$\begin{array}{l}\text { Sirte Basin Subcrop AU } \\
\text { (20540305) }\end{array}$} & 0 il & 0 & 18 & 86 & 26 & 0 & 35 & 175 & 52 & 0 & 1 & 7 & 2 \\
\hline & Gas & & & & & 0 & 0 & 0 & 0 & 0 & 0 & 0 & 0 \\
\hline $\begin{array}{l}\text { Total undiscovered petroleum } \\
\text { resources, Hamra Basin }\end{array}$ & & 179 & 704 & 1,658 & 784 & 1,053 & 4,179 & 10,414 & 4,748 & 79 & 325 & 871 & 381 \\
\hline
\end{tabular}

